\title{
PARTIAL DIALLEL TO EVALUATE THE COMBINING ABILITY FOR ECONOMICALLY IMPORTANT TRAITS OF PAPAYA
}

\author{
Sergio Lucio David Marin ${ }^{1}$; Messias Gonzaga Pereira ${ }^{2 *}$; Antonio Teixeira do Amaral Júnior²; \\ Luiz Aurélio Peres Martelleto ${ }^{3}$; Carlos David Ide ${ }^{3}$ \\ ${ }^{I}$ FAESA, Campus II - Faculdades Integradas São Pedro - Rod. Serafim Derenzi, 3.115, São Pedro - 29030-001 - \\ Vitória, ES - Brasil. \\ ${ }^{2}$ UENF - Lab. de Melhoramento Genético Vegetal - Av. Alberto Lamego, 2000, Parque Califórnia - 28013-602 - \\ Campos dos Goytacazes, RJ - Brasil. \\ ${ }^{3}$ PESAGRO-RIO - Estrada Velha do Glicério, km 3, Horto - 27901-970 - Macaé, RJ - Brasil. \\ *Corresponding author<messias@uenf.br>
}

\begin{abstract}
The dependence of Brazil on imported improved papaya seeds was the main motivation for this research that primarily intended to evaluate the combining ability of eight genotypes from the 'Solo' group, crossed with eight genotypes from the 'Formosa' group following a partial diallel scheme. The traits mean fruit weight, brix degree and flavor revealed prevalence of additive effects in both genetic groups, while plant height was preponderantly additive only for the 'Solo' genotypes. On the other hand, the yield trait expressed additive superiority for the 'Formosa' genotypes. For intrapopulation breeding for higher yield, the indicated genotypes are 'Maradol' and 'Cariflora' from the 'Formosa' group as well 'Sunrise Solo 783' and 'Sunrise Solo TJ' from the 'Solo' group; but, when the objective is to breed for better fruit quality, the genotypes 'JS 12' and 'JS 11' ('Formosa' group), and 'Sunrise Solo72/12' and 'Baixinho de Santa Amália' ('Solo' group) are indicated. Based on the set of evaluated traits, the best hybrid combinations were 'Sunrise Solo $72 / 12 \times$ JS 12', 'Sunrise Solo TJ $\times$ JS 12', 'Baixinho de Santa Amália $\times$ JS 12', 'Sunrise Solo TJ X JS 11' and 'Sunrise Solo 72/12 × Costa Rica'.
\end{abstract}

Key words: Carica papaya L., heterosis, hybrids

\section{DIALELO PARCIAL PARAAVALIARACAPACIDADE COMBINATÓRIA DE CARACTERÍSTICAS DE IMPORTÂNCIA ECONÔMICADO MAMOEIRO}

\begin{abstract}
RESUMO: A dependência do Brasil por sementes melhoradas de mamoeiro foi a principal motivação para a implementação deste trabalho que fundamentalmente objetivou avaliar a capacidade combinatória de oito genitores do grupo 'Solo' em cruzamento dialélico parcial com oito genótipos do grupo 'Formosa'. As características peso médio dos frutos, teor de graus brix e degustação de sabor revelaram prevalência de efeitos aditivos em ambos os grupos, ao passo que altura de planta foi preponderantemente aditiva somente para os materiais do grupo 'Solo'. Por outro lado, a produtividade expressou superioridade aditiva apenas para o grupo 'Formosa'. Para o melhoramento intrapopulacional visando maiores produtividades, são indicados os genitores 'Maradol' e 'Cariflora', do grupo 'Formosa', e 'Sunrise Solo 783' e 'Sunrise Solo TJ', do grupo 'Solo'; por sua vez, quando se visam melhorias para a qualidade do fruto, merecem destaque os genitores 'JS 12' e 'JS 11', do grupo 'Formosa', e 'Sunrise Solo 72/12' e 'Baixinho de Santa Amália', do grupo 'Solo'. Os híbridos 'Sunrise Solo 72/12 $\times$ JS 12', 'Sunrise Solo TJ $\times$ JS 12', 'Baixinho de Santa Amália $\times$ JS 12', 'Sunrise Solo TJ $\times$ JS 11' e 'Sunrise Solo $72 / 12 \times$ Costa Rica' foram superiores para o conjunto de características avaliadas.
\end{abstract}

Palavras-chave: Carica papaya L., heterose, híbridos

\section{INTRODUCTION}

Brazil is a large fruit producing country that harvested about 3,300,000 tons of papaya over an area of 40,000 hectares in 2000 (Agrianual, 2002). Until recently all this production was due to the cultivation of hybrids of Chinese origin, of the 'Formosa' group and Hawaiian cultivars, of the 'Solo' group (Pereira, 2003). Currently the North of Espirito Santo State accounts for $69.7 \%$ of the national papaya ex- 
portation for fresh consumption (BRAPEX, 2005) to the United States, Singapore, Hong Kong, China, Japan and Canada (Rangel, 2002).

The high price of hybrid seeds of the 'Formosa' papaya, generally imported from Kaohsiung - Taiwan for US\$ 3500-4000 per kg has stimulated many fruit producers in Brazil to use seeds in successive higher generations, like $\mathrm{F}_{2}, \mathrm{~F}_{3}$ and $\mathrm{F}_{4}$ of the 'Tainung 01 ' hybrid, resulting in less vigor and expressive segregation for the fruit shape (Marin et al., 2001). The most cropped cultivar in Brazil, 'Sunrise Solo' ('Solo') has yield limited to 40 to $60 \mathrm{t} \mathrm{ha}^{-1}$ and is very susceptible to the mosaic virus. The fruit skin commonly presents physiological spot symptoms and the pulp is not very firm, that causes post harvest losses, especially for exportation.

Thus it is unquestionable that papaya breeding is a relevant option for Brazil to reduce dependence on seeds from the external market, that results in greater income for the growers.

The edaphoclimatic similarity of the North Fluminense region with the main Brazilian papaya producing region motivated researchers at the Universidade Estadual do Norte Fluminense Darcy Ribeiro to begin a papaya breeding program in 1995 . The present research aimed to examine the general combining ability of parents of the 'Solo' and 'Formosa' groups and the specific combining ability of the hybrids resulting from a partial diallel cross design. A further objective of the research was the identification of hybrids with desirable traits for domestic and foreign markets.

\section{MATERIAL AND METHODS}

Sixteen genitors, eight from each papaya groups ('Solo' and 'Formosa'), from the Brazilian Germplasm Banks located at Universidade Estadual do Norte Fluminense Darcy Ribeiro - UENF and Empresa Brasileira de Pesquisa Agropecuária - EMBRAPA were used. The genotypes were selected based on their divergence in terms of morphoagronomic traits (Marin et al., 2006). The parents of the 'Solo' group were 'Sunrise Solo-TJ' (open pollinated variety in the $\mathrm{S}_{2}$ generation), 'Sunrise Solo-72/12-IS' (open pollinated variety), 'Santa Bárbara' (open pollinated elite inbred line), 'Baixinho de Santa Amália' (open pollinated variety), 'São Mateus' (elite inbred line in the $\mathrm{S}_{1}$ generation), 'Sunrise Solo-783' (open pollinated variety in the $\mathrm{S}_{1}$ generation), 'Waimanalo' (open pollinated variety), and 'Kapoho-Solo' (open pollinated variety in the $\mathrm{S}_{2}$ generation). The parents of the 'Formosa' group were: 'Dióico Amarelo' (open pollinated variety), 'Maradol Roxo' (open pollinated variety in the $\mathrm{S}_{2}$ generation), 'JS 12' (open pollinated variety in the $\mathrm{S}_{2}$ generation),
'JS 11' (open pollinated variety in the $\mathrm{S}_{2}$ generation), 'Tailândia A' (open pollinated variety in the $S_{2}$ generation), 'DCG 440-3 Costa Rica' (elite inbred line in the $\mathrm{S}_{2}$ generation), 'Tainung $01 / 781$ ' (hybrid in the $\mathrm{F}_{2}$ generation), and 'Cariflora' (open pollinated variety).

The hybrid seeds were obtained in Casimiro de Abreu, Rio de Janeiro State, Brazil. The crosses were carried out in a partial diallel scheme, by pollen transference from hermaphrodite or male plants of the 'Formosa' genitors to stigmas of female plants of the 'Solo' genitors.

The experiment was conducted from March 2001 to January 2002, in Linhares, ES, Brazil, $\left(19^{\circ} 23^{\prime} 48^{\prime \prime} \mathrm{S}, 40^{\circ} 03^{\prime} 42^{\prime \prime} \mathrm{W}\right)$ in a randomized complete block design with four replications in 80 treatments (64 hybrids and 16 parents). A single row plot was used, spaced $3.60 \mathrm{~m}$ between row and $1.8 \mathrm{~m}$ between plant, and 8 plants per plot.

Six seedlings were planted per hole for each treatment, spaced $20 \mathrm{~cm}$ apart. Thinning left a single papaya plant after the determination of the gender. In the case of the genotypes derived from dioecious populations, the maximum possible number of female plants was maintained after sexing. For the genotypes derived from gynoecious-andromonoecious populations the maximum possible number of hermaphrodite plants was maintained because of the high commercial value of the produced fruits. The crop was managed in the field according to the recommendations by Marin et al. (1995).

The following traits were evaluated: a) total fruit yield (TFY) - expressed in grams, obtained by the multiplication of the fruit number by the mean fruit weight per plant, 270 days after transplanting the seedlings to the field; b) mean fruit weight (MFW) expressed in grams obtained by weighting on an analytical scale a three-fruit sample of each plant weekly harvested; c) plant height (PH) - expressed in $\mathrm{cm}$, measured with a ruler, from the ground level up to the last leaf pair on the stem apex of the papaya tree, 120 days after transplanting; d) soluble solids (BRIX) content - expressed in degree brix, obtained by using a manual refractometer on a three-fruit sample of each plant at each harvest; and j) taste degustation (TD) obtained by scoring the fruit pulp taste of three-fruit samples of each plant and each harvest, according to scale established by the Quality Control and Post Harvest Laboratory of the Caliman Agrícola S/A Company ( 4 = optimum, 3 = good, $2=$ regular, $1=$ poor $)$.

The Griffing Model (1956), Method 2 (inclu-

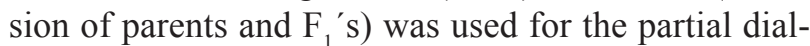
lel cross scheme, considering Model 1 (adopting the genotype effects as fixed). The following genetic statistical model was considered: $\mathrm{Y}_{\mathrm{ij}}=\mu+\mathrm{g}_{\mathrm{i}}+\mathrm{g}_{\mathrm{j}}{ }+\mathrm{s}_{\mathrm{ij}}+$ 
$\bar{\varepsilon}_{\mathrm{ij}}$, where: $\mathrm{Y}_{\mathrm{ij}}=$ mean value of the hybrid combination involving the $\mathrm{i}$-th parent of group 1 and the $\mathrm{j}$-th parent of group 2; $\quad=$ general mean; $g_{i}=$ effects of the general combining ability (GCA) of the $i$-th parent of group 1; $g_{j}=$ effect of the GCA of the j-th parent of group 2; $\mathrm{s}_{\mathrm{ij}}=$ effect of the specific combining ability (SCA) of the hybrid combination involving the i-th parent of group 1 and the $\mathrm{j}$-th parent of group 2; and

$=$ mean experimental error (Cruz \& Regazzi, 2001). The Genes Program (Cruz, 2001) was used to carry out the analysis.

\section{RESULTS AND DISCUSSION}

The parent's mean square magnitudes were highly significant at the $1 \%$ level of probability by the F test, for all the assessed traits, showing the existence of real differences among the genotypes used as parents in the composition of the partial diallel design (Table 1). Partitioning the effects, the group 1 presented significance only for PH and BRIX, indicating a high similarity among the parents in the 'Solo' group. Such group, in fact presents genotypes phenotypicaly alike probably sharing expressive magnitude of common alleles. On the other hand, the group 2, Formosa genotypes, was highly significant at the $1 \%$ of probability level by the F test for all the assessed traits, showing more expressive genetic diversity for this group of parents. Regarding the G1 × G2 interaction, only $\mathrm{PH}$ was not significant, showing that the groups were distinct and that the partial diallel design might produce good combinations.
The parent $\mathrm{x}$ crossing interaction was significant for most of the traits, except for BRIX, which evidenced the existence of genetic differences among the parents and their hybrid combinations, one of the essential conditions for the expression of heterosis (Table 1).

The estimates of the effects of the mean squares of the general and specific combining ability (GCA and SCA, respectively) were in general significant at $1 \%$ of probability level by the $\mathrm{F}$ test indicating that both the additive and non-additive genetic effects were involved in the control of the evaluated traits. More specifically, additive genetic effects prevailed for the genotypes of the 'Solo' group for MFW, PH, BRIX and TD; while for the 'Formosa' group, additive effects were predominant for TFY, MFW, BRIX and TD. Only BRIX was not significant for the among group interaction, indicating that superior hybrids might be obtained for almost all the assessed traits. The absence of significance for BRIX for the effects of SCA $(\mathrm{G} 1 \times \mathrm{G} 2)$ and parents $x$ crossing interactions was an indication of probably no importance of dominance deviations for this trait.

Concerning the effects for TFY, the genotypes that showed higher potentials to improve fruit yield for intrapopulation breeding were: 'Sunrise Solo 783', 'Sunrise Solo TJ', 'Waimanalo Solo' and 'Kapoho Solo' in the 'Solo' group, and 'Maradol Roxo' and 'Cariflora' in the 'Formosa' group (Table 2).

The greatest positive $\hat{g}_{i}$ magnitudes for MFW were shown by 'Maradol Roxo' and 'JS 12' in the

Table 1 - Analysis of variance with the partitioning of the sum of the squares of parents and crosses in the sums of associated squares, respectively, of group 1 ('Solo') and group 2 ('Formosa') of papaya and the general combining ability for five morphoagronomic traits assessed in a partial diallel cross design.

\begin{tabular}{|c|c|c|c|c|c|c|}
\hline \multirow{2}{*}{ Source } & \multirow{2}{*}{$\mathrm{DF}$} & \multicolumn{5}{|c|}{ Mean Squares of Traits ${ }^{1}$} \\
\hline & & TFY & MFW & $\mathrm{PH}$ & BRIX & TD \\
\hline Genotypes & 79 & $334209684.59 * *$ & $505504.41 * *$ & $588.99 * *$ & $3.97 * *$ & $2.04 * *$ \\
\hline Parents & 15 & $603465343.86^{* *}$ & $1098222.80 * *$ & $975.19 * *$ & $9.60 * *$ & $1.77 * *$ \\
\hline Group 1 & 7 & $54825826.60^{\mathrm{ns}}$ & $49473.03^{\mathrm{ns}}$ & $1625.15 * *$ & $4.27 * *$ & $0.83^{\mathrm{ns}}$ \\
\hline Group 2 & 7 & $416441520.88 * *$ & $638561.10 * *$ & $463.73 * *$ & $4.67 * *$ & $2.31 * *$ \\
\hline $\mathrm{G} 1 \times \mathrm{G} 2$ & 1 & $5753108725.56^{* *}$ & $11657103.06^{* *}$ & $5.736^{\mathrm{ns}}$ & $81.36^{* *}$ & $4.51 * *$ \\
\hline Parents $\times$ Crosses & 1 & $4604425132.78 * *$ & $4582954.12 * *$ & $6555.59 * *$ & $3.57^{\mathrm{ns}}$ & $3.61 * *$ \\
\hline Crosses & 63 & $202319996.69 * *$ & $299659.56 * *$ & $402.33 * *$ & $2.63 * *$ & $2.08 * *$ \\
\hline GCA (Group 1) & 7 & $195605955.28^{\mathrm{ns}}$ & $1079817.48 * *$ & $1277.04 * *$ & $5.90 * *$ & $1.08 * *$ \\
\hline GCA (Group 2) & 7 & $462483474.30 * *$ & $884215.27 * *$ & $194.36^{\mathrm{ns}}$ & $8.21 * *$ & $13.16^{* *}$ \\
\hline SCA (G1 x G2) & 49 & $166112934.38 * *$ & $104700.47 * *$ & $307.09 * *$ & $1.37^{\mathrm{ns}}$ & $0.64 * *$ \\
\hline Error & 237 & 72857484.14 & 33798.24 & 192.97 & 1.19 & 0.24 \\
\hline
\end{tabular}

${ }^{1} \mathrm{TFY}=$ total fruit yield at 270 days after transplanted; MFW = mean fruit weight; $\mathrm{PH}=$ plant height; BRIX $=$ soluble solid contents of the fruit pulp; $\mathrm{TD}=$ flavor assessment.* and $* *$ significant, respectively, at levels of 5 and $1 \%$ probability by the $\mathrm{F}$ test and ns non significant. 
Table 2 - Estimates of GCA effects $\left(\hat{\mathrm{g}}_{\mathrm{i}}\right)$ for five traits assessed in a partial diallel cross design among 16 parents of papaya of the 'Solo' and 'Formosa' groups.

\begin{tabular}{|c|c|c|c|c|c|}
\hline \multirow[b]{2}{*}{ Cultivars } & \multicolumn{5}{|c|}{ Traits $^{1}$} \\
\hline & TFY & MFW & $\mathrm{PH}$ & BRIX & TD \\
\hline \multicolumn{6}{|l|}{ Group 1} \\
\hline 1. Sunrise TJ & 2564.22 & -57.30 & 9.30 & 0.55 & -0.03 \\
\hline 2. Sunrise $72 / 12$ & -5095.43 & -251.80 & 5.64 & 0.18 & 0.03 \\
\hline 3. $\mathrm{St}^{\mathrm{a}}$ Bárbara & 542.91 & 177.78 & -1.09 & -0.71 & -0.12 \\
\hline 4. São Mateus & -1077.15 & 6.97 & -5.41 & -0.23 & 0.18 \\
\hline 5. B. $\mathrm{St}^{\mathrm{a}}$ & -745.08 & -98.08 & -9.30 & 0.41 & 0.21 \\
\hline 6. Sunrise 783 & 2696.03 & 60.12 & -4.57 & -0.32 & 0.15 \\
\hline 7. Waimanalo & 975.75 & 317.22 & 0.73 & -0.16 & -0.12 \\
\hline 8. Kapoho & 138.75 & -154.90 & 4.71 & 0.29 & -0.31 \\
\hline \multicolumn{6}{|c|}{ Group 2 (Formosa (Formosa) } \\
\hline 1'. Dióico & 1101.66 & 3.66 & -3.53 & -0.36 & -0.81 \\
\hline 2'. Maradol Roxo & 6170.59 & 317.44 & 0.46 & -0.93 & -0.59 \\
\hline 3'. JS 11 & -4238.15 & -96.77 & 0.47 & 0.81 & 0.75 \\
\hline 4'. JS 12 & -1718.74 & 143.84 & 0.80 & 0.07 & 0.65 \\
\hline 5'. Costa Rica & -1680.40 & -141.08 & 4.56 & 0.13 & -0.78 \\
\hline 6'. Tailândia & -1649.83 & -182.93 & -2.53 & 0.28 & 0.06 \\
\hline 7'. Tainung 01 & -3078.30 & -86.24 & 0.78 & 0.06 & 0.34 \\
\hline 8'. Cariflora & 5093.19 & 42.09 & -1.02 & -0.06 & 0.37 \\
\hline
\end{tabular}

TFY = total fruit yield at 270 days after transplants; MFW = mean fruit weight; $\mathrm{PH}=$ plant height; BRIX = soluble solids content of the fruit pulp; TD = flavor assessment. (1) Sunrise Solo TJ; (2) Sunrise Solo 72/12; (3) Santa Bárbara; (4) São Mateus; (5) Baixinho de Santa Amália; (6) Sunrise Solo 783; (7) Waimanalo Solo; (8) Kapoho Solo; (1') Dióico; (2') Maradol Roxo; (3') JS 11; (4') JS 12; (5') Costa Rica; (6') Tailândia; (7') Tainung 01; (8') Cariflora.

'Formosa' group, and 'Waimanalo' and 'Santa Bárbara' in the 'Solo' group, indicating that these cultivars tended to contribute genetically to increase fruit weight. This was expected, because these cultivars have been characterized by presenting mean fruit weights of superior magnitude (Marin \& Gomes, 2000). In opposite, the greatest negative $\hat{\mathrm{g}}_{\mathrm{i}}$ magnitude occurred for 'Sunrise Solo 72/12', 'Tailândia' and 'Kapoho Solo', that showed the possibility of indicating these cultivars for breeding programs aiming the reduction of fruit size.

About PH, the genotypes 'Baixinho de Santa Amália' and 'São Mateus', from the 'Solo' group, were prominent since they presented the greatest negative $\hat{\mathrm{g}}_{\mathrm{i}}$ estimates, respectively -9.30 and -5.41 (Table 2). Regarding the parents in the 'Formosa' group, the greatest negative $\hat{\mathrm{g}}_{\mathrm{i}}$ magnitudes occurred for the 'Dióico' and 'Tailândia' cultivars expressed by their respective estimates of -3.53 and -2.53 . When the magnitudes of the $\hat{\mathrm{g}}_{\mathrm{i}}$ estimates were compared considering both papaya groups, in general the 'Solo' genetic group presented more promising materials to obtaining genotypes with reduced plant height.
The best performing cultivars for the BRIX trait, with their respective positive $\hat{g}_{i}$ magnitudes, were 'JS 11' (0.81), in the 'Formosa' group, followed by 'Sunrise Solo TJ' (0.55), 'Baixinho de Santa Amália' (0.41) and 'Kapoho Solo' (0.29), in the 'Solo' group. So, there were genotypes in the two groups that could contribute to increase the soluble solids content of the fruit in breeding programs for this purpose.

Considering the TD trait, the greatest positive $\hat{\mathrm{g}}_{\mathrm{i}}$ estimates were expressed by 'JS 11' $(0.75)$ and 'JS 12 ' $(0.65)$, in the 'Formosa' group and by 'Baixinho de Santa Amália' (0.21), 'São Mateus' (0.18) and 'Sunrise Solo 783' (0.15) in the 'Solo' group. This showed that these cultivars could be indicated for intrapopulation breeding programs to improve fruit pulp flavor.

The estimates of the SCA $\left(\hat{\mathrm{s}}_{\mathrm{ij}}\right)$ effects showed that for $\mathrm{PH}$ the $8 \times 2$ ', $3 \times 3$ ' and $2 \times 2^{\prime}$ combinations presented the greatest negative effects (Table 3 ), despite the positive values for their parents. In contrast, parents 5 ('Baixinho de Santa Amália') and 1' ('Dióico'), even though they presented the greatest negative $\hat{\mathrm{g}}_{\mathrm{i}}$ magnitudes for $\mathrm{PH}$ in their groups (Table 2 ), the respective hybrid combination $5 \times 1$ ' expressed 


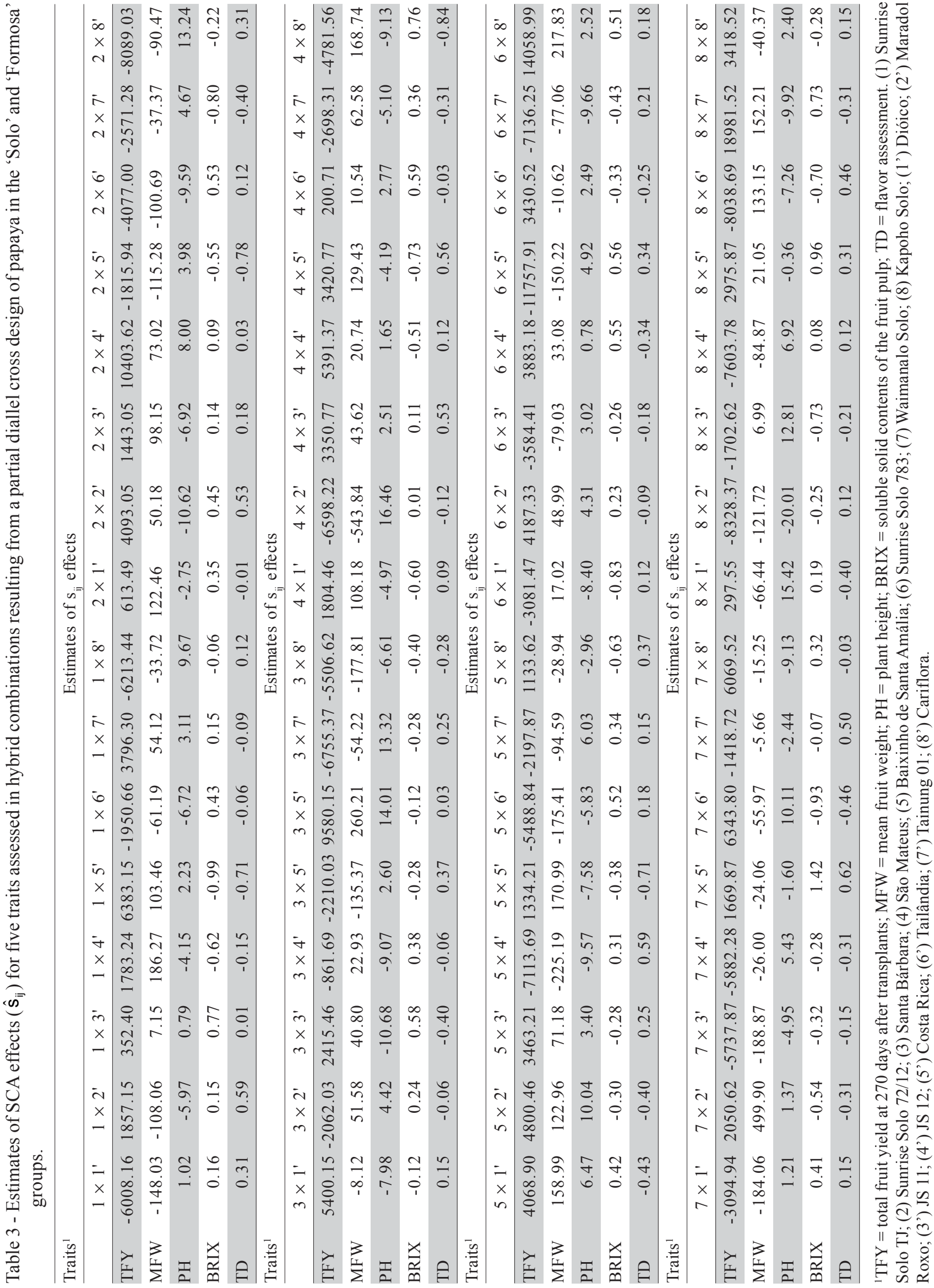


a positive $\hat{\mathrm{s}}_{\mathrm{ij}}$ value, with magnitude 6.47 (Table 3). Such situation - expected results based on the $\hat{g}_{i}$ estimates in disagreement with the respective hybrid's performances - is a good indication of significant dominance deviation and consequently, the possibility of obtaining significant heterosis.

Concerning MFW, the hybrids with the greatest positive effects for $\hat{s}_{\mathrm{ij}}$ were: $7 \times 2$ ', $3 \times 6 \times 6 \times$ $8^{\prime}, 1 \times 4^{\prime}, 5 \times 5^{\prime}, 4 \times 8^{\prime}, 5 \times 1^{\prime}, 8 \times 7^{\prime}, 8 \times 6^{\prime}$ and 4 $\times 5^{\prime}$ ' (Table 3 ). The $7 \times 2$ ', $3 \times 6$ ' and $1 \times 4$ ' combinations were outstanding since they also presented parents with greater GCA effect (Table 2). This indicates that parents 2' ('Maradol Roxo'), 7 ('Waimanalo Solo'), 3 ('Santa Bárbara') and 4' ('JS 12') were the most suitable genotypes to increase the mean fruit weight in papaya breeding programs.

The greatest negative $\hat{\mathrm{s}}_{\mathrm{ij}}$ magnitudes for MFW occurred in the $4 \times 2^{\prime}, 5 \times 4^{\prime}, 7 \times 3^{\prime}, 7 \times 1^{\prime}, 3 \times 8^{\prime}$, $5 \times 6^{\prime}, 6 \times 5^{\prime}, 1 \times 1^{\prime}, 3 \times 5^{\prime}$ and $8 \times 2^{\prime}$ hybrids (Table $3)$. Almost all these combinations, in addition to the negative SCA, presented at least one of the parents with high negative GCA magnitude. Thus these hybrids were also more promising when the objective was to obtain genotypes with lower fruit weight. The genotypes 2 ('Sunrise Solo 72/12'), 6' ('Tailândia'), 8 ('Kapoho Solo'), 5' ('Costa Rica'), 5 ('Baixinho de Santa Amália') and 3' ('JS 11') may be used as parents in breeding programs to reducing papaya fruit weight.

Regarding the TFY trait, the combinations with positive superior $\hat{\mathbf{s}}_{\mathrm{ij}}$ estimates derived from parents with positive $\hat{\mathrm{g}}_{\mathrm{i}}$ estimates were: $8 \times 7^{\prime}, 6 \times 8^{\prime}, 3 \times 6^{\prime}, 7 \times$ 6', $1 \times 5^{\prime}, 5 \times 2^{\prime}, 7 \times 8^{\prime}$ ' and $3 \times 1^{\prime}$ ', indicating that the parents 'Sunrise Solo 783', 'Cariflora', 'Kapoho Solo', 'Waimanalo Solo', 'Maradol Roxo' and 'Sunrise Solo TJ' may generate superior segregants for total fruit yield in papaya breeding programs.

The hybrids with greatest positive $\hat{\mathrm{s}}_{\mathrm{ij}}$ estimates for the BRIX trait were: $7 \times 5^{\prime}, 8 \times 5^{\prime}, 4 \times 8^{\prime}, 1 \times$ $3^{\prime}, 8 \times 7^{\prime}, 4 \times 6^{\prime}, 3 \times 3^{\prime}, 6 \times 5^{\prime}, 6 \times 4^{\prime}$ and $2 \times 6^{\prime}$. Only the $4 \times 8^{\prime}$ combination derived from parents with negative $\hat{g}_{i}$ estimates showed that this hybrid performed better than expected based on the parental GCA. In contrast, the $8 \times 5^{\prime}, 1 \times 3^{\prime}, 8 \times 7^{\prime}$ and $2 \times$ 6 ' combinations derived from crossing between parents that expressed positive $\hat{g}_{i}$ estimates, showed that the hybrids performed as expected based on the parental GCA. The parents 'Kapoho Solo', 'Costa Rica', 'Sunrise Solo TJ', 'JS 11', 'Costa Rica', 'Tainung 01', 'Sunrise Solo 72/12', 'Tailândia' and 'JS 12' may contribute genetically to increasing the soluble solid contents of the papaya fruits.

For the TD trait, the $7 \times 5^{\prime}, 5 \times 4^{\prime}, 1 \times 2^{\prime}, 4$ $\times 5^{\prime}, 4 \times 3^{\prime}, 2 \times 2^{\prime}, 7 \times 7^{\prime}, 8 \times 6^{\prime}, 3 \times 5^{\prime}$ and $5 \times 8^{\prime}$ combinations expressed the greatest positive $\hat{s}_{i j}$ values (Table 3), of which $7 \times 5^{\prime}, 1 \times 2^{\prime}$ and $3 \times 5^{\prime}$ ' performed better than expected based on their parental GCA (Table 2). The combinations $5 \times 4$ ', $4 \times 3$ ' and $5 \times 8^{\prime}$ 'derived from parents that expressed positive $\hat{g}_{i}$ estimates (Table 2) performed as expected, based on their parental GCA. Consequently, the 'JS 12', 'Baixinho de Santa Amália', 'JS 11', 'Cariflora' and Tainung 01' cultivars may be recommended as parents for papaya breeding to improve fruit pulp flavor.

Based on the traits directly associated to yield, the 'Maradol' and 'Cariflora' parents in the 'Formosa' group and 'Sunrise Solo 783' and 'Sunrise Solo TJ' in the 'Solo' group were outstanding for their $\hat{g}_{i}$ magnitudes and may be indicated for intrapopulation breeding. Further for intrapopulation breeding for the traits associated to fruit quality, the parents 'JS 12' and 'JS 11 ' in the 'Formosa' group and 'Sunrise Solo 72/12' and 'Baixinho de Santa Amália' in the 'Solo' group were outstanding because of the $\hat{\mathrm{g}}_{i}$ magnitudes, and may be indicated for intrapopulation breeding. Considering the set of traits and the importance of the qualitative attributes for papaya consumption, the best combinations were: 'Sunrise Solo $72 / 12 \times$ JS 12', 'Sunrise Solo TJ $\times$ JS 12', 'Baixinho de Santa Amália $\times$ JS 12', 'Sunrise Solo TJ $\times$ JS 11' and 'Sunrise Solo $72 / 12 \times$ Costa Rica'.

\section{CONCLUSIONS}

There was major difference between the genotypes of the 'Solo' group as compared to the genotypes of the 'Formosa' group. For intrapopulation breeding programs for higher yield, the best parents were 'Maradol' and 'Cariflora' of the 'Formosa' group and 'Sunrise Solo 783' and 'Sunrise Solo TJ' of the 'Solo' group. For intrapopulation breeding programs for fruit quality, the best parents were 'JS 12' and 'JS 11', of the 'Formosa' group and 'Sunrise Solo 72/12' and 'Baixinho de Santa Amália' of the 'Solo' group. Considering the set of traits, the following hybrids may be selected: 'Sunrise Solo $72 / 12 \times$ JS 12', 'Sunrise Solo TJ $\times$ JS 12', 'Baixinho de Santa Amália $\times$ JS 12', 'Sunrise Solo TJ $\times$ JS 11' and 'Sunrise Solo $72 / 12 \times$ Costa Rica'.

\section{REFERENCES}

AGrianual. Anuário da Agricultura Brasileira. São Paulo: FNP, 2002. 536p.

ASSOCIAÇÃO BRASILEIRA DE EXPORTADORES DE PAPAYA - BRAPEX. Available in: <http://www.brapex.net> Accessed at: set. 2005.

CRUZ, C.D. Programa Genes: Versão Windows; aplicativo computacional em genética e estatística. Viçosa: UFV, 2001. 648 p. 
CRUZ, C.D.; REGAZZI, A.J. Modelos biométricos aplicados ao melhoramento genético. Viçosa: UFV, 2001. 390p.

GRIFFING, B. Concept of general and specific combining ability in relation to diallel crossing systems. Australian Journal of Biological Sciences, v.9, p.463-493, 1956.

MARIN, S.L.D.; GOMES, J.A. Técnicas do cultivo do mamão. In: SEMANA INTERNACIONAL DE FRUTICULTURA E AGROINDÚstRIA, 7., Fortaleza, 2000. Anais. Fortaleza: SINDIFRUTA - FRUTAL, 2000. 57p.

MARIN, S.L.D.; GOMES, J.A.; SALGADO, J.S.; MARTINS, D.S.; FULLIN, E.A. Recomendações para a cultura do mamoeiro dos grupos Solo e Formosa no Estado do Espírito Santo. 4.ed. Vitória: INCAPER, 1995. 57p. (Circular Técnica, 3).

MARIN, S.L.D.; PEREIRA, M.G.; FERREGUETTI, G.A.; AMARAL JR, A.T.; CATTANEO, L.F. Capacidade combinatória em mamoeiro (Carica papaya L.) dos grupos 'Solo' e 'Formosa' sob cruzamento dialélico parcial. In: CONGRESSO BRASILEIRO DE MELHORAMENTO DE PLANTAS, 1., Goiânia, 2001. Anais. Goiânia: Sociedade Brasileira de Melhoramento de Plantas, 2001.
MARIN, S.L.D.; PEREIRA, M.G.; AMARAL JR., A.T.; MARTELLETO, L.A.P.; IDE, C.D. Heterosis in papaya hybrids from partial diallel of 'Solo' and 'Formosa' parents. Crop Breeding and Applied Biotechnology, v.6, p.24-29, 2006.

PEREIRA, M.G. Melhoramento genético do mamoeiro (Carica papaya L.): desenvolvimento e recomendação de híbridos. In: FEITOSA, C. Seahortes. Alegre: CCA-UFES, 2003. p.61-65. RANGEL, S.B. Comportamento do mercado do mamão no Distrito Federal - DF. Brasília: UnB, 2002. 67p. (Dissertação - MS).

Received February 17, 2006

Accepted October 02, 2006 